\title{
Effect of cryoprotectant on the motility, viability, fertilization, and DNA integrity of naleh fish Barbonymus sp. (Cyprinidae) sperm
}

\author{
Efeito do crioprotetor na motilidade, viabilidade, fertilização e \\ integridade do DNA no sêmen de peixes naleh Barbonymus sp. \\ (Cyprinidae)
}

\author{
Siti Maulida ${ }^{1,2}$; Kartini Eriani ${ }^{1}$ (D); Firman Muhammad Nur ${ }^{3}$ (D); Nur Fadli² (D); Agung Setia Batubara ${ }^{4}$ (D); \\ Abdullah Adan Muhammadar ${ }^{3}$ (D); Mohd Nor Siti-Azizah ${ }^{5}$ (D); Martin Wilkes ${ }^{6}$ (D); Zainal Abidin Muchlisin ${ }^{2,7}$ \\ ${ }^{1}$ Universitas Syiah Kuala, Faculty of Mathematics and Natural Sciences, Master Program in Biology, Banda Aceh, Indonesia \\ ${ }^{2}$ Universitas Syiah Kuala, Faculty of Marine and Fisheries, Department of Aquaculture, Banda Aceh, Indonesia \\ ${ }^{3}$ Universitas Syiah Kuala, Doctoral Program in Mathematics and Sciences Application, Banda Aceh, Indonesia \\ ${ }^{4}$ Universitas Negeri Medan, Faculty of Mathematics and Natural Sciences, Medan, Indonesia \\ ${ }^{5}$ Universiti Malaysia Terengganu, Institute of Marine Biotechnology, Terengganu, Malaysia \\ ${ }^{6}$ Coventry University, Center for Agroecology, Water and Resilience, Coventry, United Kingdom \\ ${ }^{7}$ Universitas Syiah Kuala, Marine and Fisheries Research Center, Banda Aceh, Indonesia
}

\begin{abstract}
Naleh fish Barbonymus sp. is a commercial freshwater fish, which is indigenous to Aceh, Indonesia. The population of this species has declined over the years as a result of habitat perturbations and overfishing. Hence, the crucial need to develop a cryopreservation method to support breeding programs. This involved the use of a cryoprotectant as an important component. The objective of this study, therefore, was to explore the best cryoprotectant for naleh fish spermatozoa, and a total of five types were tested. These include the DMSO, Methanol, Ethanol, Glycerol, and Ethylene Glycol at a similar concentration of $10 \%$, which were individually combined with $15 \%$ egg yolk, and every treatment was performed in three replications. Conversely, Ringer's solution was adopted as an extender, and the sperm was cryopreserved in liquid nitrogen for 15 days. The results showed significant influence on sperm motility and viability, as well as egg fertility of naleh fish $(\mathrm{P}<0.05)$, although the DMSO provided the best outcome, compared to others at $47.17 \%, 50.13 \%$, and $45.67 \%$, respectively. Furthermore, DNA fragmentation had not occurred in the fresh and cryopreserved sperm samples, indicating the protective effect of tested cryoprotectants. It is concluded that the $10 \%$ DMSO and 15\% egg yolk is the best cryoprotectant for naleh fish spermatozoa.
\end{abstract}

Keywords: Dimethylsulfoxide. Ringer. DNA fragmentation. Cryoprotectant.

\section{RESUMO}

O peixe naleh Barbonymus sp. é um peixe comercial de água doce, originário de Aceh, Indonésia. Durante vários anos, as perturbações provocadas no seu habitat e a pesca predatória determinaram o declínio da sua população, cuja preservação deve apoiar-se em um programa de reprodução controlada, com o emprego de espermatozoides criopreservados. O presente trabalho realizou um estudo comparativo de cinco crioprotetores: dimetilsultóxido, metanol, etanol, glicerol e etileno glicol. Todos os crioprotetores foram testados na concentração de 10\%, combinados a 15\% de gema de ovo. Cada tratamento foi efetuado em triplicatas. A solução de ringer foi utilizada como extensor e o esperma foi criopreservado em nitrogênio líquido por 15 dias. Os resultados obtidos revelaram a existência de influência significante $(\mathrm{P}<0,05)$ na viabilidade e motilidade espermática bem como na fertilidade dos ovos do peixe naleh, em que o dimetilsulfóxido apresentou o melhor resultado com os valores de 47,17\%, 50,13\% e 45,67\%, respectivamente. Por outro lado, a fragmentação do DNA não ocorreu nas amostras de esperma fresco e criopreservado, indicando o efeito protetor dos crioprotetores testados. A conclusão obtida foi que o dimetilsulfóxido e 15\% de gema de ovo foram o melhor crioprotetor para os espermatozoides do peixe naleh.

Palavras-chave: Dimetilsulfóxido. Solução de Ringer. Fragmentação de DNA. Crioprotetor. 
Correspondence to:

Zainal Abidin Muchlisin

Universitas Syiah Kuala, Faculty of Marine and Fisheries,

Department of Aquaculture

Banda Aceh 23111, Indonesia

e-mail: muchlisinza@unsyiah.ac.id

Received: April 12, 2020

Approved: May 12, 2021

How to cite: Maulida S, Eriani K, Nur FM, Fadli N, Batubara AS, Muhammadar AA, Siti-Azizah MN, Wilkes M, Muchlisin ZA. Effect of cryoprotectant on the motility, viability, fertilization, and DNA integrity of naleh fish Barbonymus sp. (Cyprinidae) sperm. Braz J Vet Res Anim Sci. 2021;58:e168702. https://doi.org/10.11606/issn.16784456.bjvras.2021.168702

\section{Introduction}

Naleh fish Barbonymus sp. is one of the native and commercial freshwater fish in the Nagan Raya waters, Aceh Province, Indonesia (Muchlisin et al., 2015a), this species has potency for intensive cultivation industry (Muchlisin, 2013). The naleh fish possess morphological similarities with B. gonionotus (Figure 1). However, both species are known to differ at a higher genetic distance, thus presumed as cryptic species, endemic to the region (Batubara et al., 2021; Batubara, 2019a). Presently, the naleh fish is known as one of the main fishing targets of local fishermen, and overfishing has resulted in a declining wild population (Batubara et al., 2019b,). This incidence has been linked with habitat perturbation, due to deforestation and illegal gold mining, and also the introduction of alien fish species, which subject a wild population to additional pressure (Batubara et al., 2018; Muchlisin, 2008, 2013). These concerns prompt the crucial need for a naleh fish conservation program. Sperm cryopreservation is one of the alternatives ways for conservating the germplasm of the fish and is one of the important methods in fish breeding.

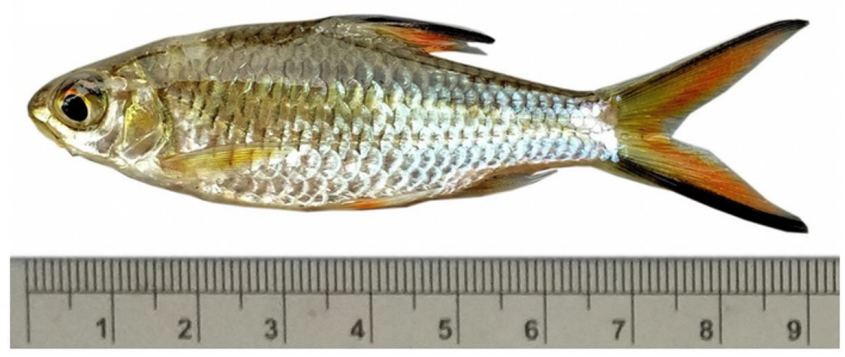

Figure 1 - The naleh fish Barbonymus sp. that occurred in Nagan Raya waters, Aceh, Indonesia (Batubara et al., 2018).
In addition, broodstock domestication is the crucial step in the fish breeding program. Presently, broodstock domestication has already been initiated by the Ichthyos Research Group, Faculty of Marine and Fisheries, Syiah Kuala University. The domesticated broodstock samples are premature and ready to spawn, as the mature variety only occurs during the early rainy season, which is similar to records from the wild population. In addition, an asynchronous maturation was detected between males and females (Batubara, 2019), hence cryopreservation is a possible method to overcome this challenge. Muchlisin et al. (2004) reported on the higher tendency to obtain sperm of better quality during the spawning season, which is then cryopreserved for use at any time of a breeding program.

Cryopreservation is a process to preserve the cells or tissues in low temperatures $\left(-196^{\circ} \mathrm{C}\right)$ (Agarwal, 2011). In fish, the first sperm cryopreservation was reported by Blaxter (1953) in herring Clupea harengus, and presently, more than 200 species of marine and freshwater fish sperm have been cryopreserved (Afriani et al., 2021; Hiemstra et al., 2005). In cryopreservation, cryoprotective agent (CPA) is known to play an important role during this process, and therefore, it must be known which type of $\mathrm{CP}$ is suitable for species to species, this is because the CPA is species dependent (Chao \& Liao, 2001; Sarder et al., 2012). There are generally two types of CPA, intracellular (ICPA) and extracellular (ECPA) (Muchlisin, 2005; Muchlisin et al., 2020). The ICPA possesses the capacity to penetrate sperm cells and confer internal protection through the formation of ice crystals, while the latter confers an external shield from temperature shock, both during cryopreservation and thawing (Muchlisin et al., 2020). Some of the commonly used intracellular CPAs include DMSO (dimethylsulfoxide), glycerol, methanol, ethanol, and ethylene glycol, while egg yolk, honey, and glucose have been adopted as extracellular. Several studies demonstrated better output while using a combination of both types, compared to an individual application. For example, Abinawanto et al. $(2013,2018)$ used a combination of methanol and egg yolk for botia Chrombotia macracanthus sperm and Java barb Barbonymus gonionotus, while Muchlisin et al. (2020) used a combination of egg yolk and DMSO for depik fish Rasbora tawarensis spermatozoa. Currently, there is no information on the preferred combination of ICPA and ECPA for naleh fish spermatozoa. Therefore, this study is considered crucial, because every cryoprotectant has peculiar advantages and disadvantages, as each fish species requires specific types and optimal concentrations. This research involved the testing of common intracellular CPAs combined with egg 
yolk to determine the best cryoprotectant for naleh fish Barbonymus sp. sperm.

\section{Materials and Methods}

\section{Experimental design}

This research involved a completely randomized experimental design. The tested ICPAs were DMSO, methanol, ethanol, glycerol, and ethylene glycol, each at a similar concentration of $10 \%$. These were individually combined with $15 \%$ egg yolk, while the control treatment was sperm without CPAs. Every test was conducted with three replications.

\section{Broodfish domestication and sperm collection}

A total of 30 male and 10 female fish were sampled from Nagan Raya waters, Aceh, Indonesia using casting nets. Fish sampling was carried out at locations that were presumed to have fish based on information from local people. The sampled fish was placed in plastic bags that contained oxygen and then was transported to the laboratory in Syiah Kuala University, Banda Aceh, Indonesia. In The laboratory, the broodfish were acclimatized in a circular plastic tank (vol. 6000L) for 14 days. Also, feeding was performed to satiation with a commercial diet, two times daily. Ten late mature samples (total length $142.75 \pm 1.16 \mathrm{~cm}$, and body weight $10.98 \pm 0.53 \mathrm{~g}$ ) were taken at random, injected with $0.5 \mathrm{ml} \mathrm{kg-1}$ body weight of Ovaprim, and then reserved in a different tank for $8 \mathrm{~h}$. Subsequently, these fish were removed from the tank and water was cleaned from their genital pore using a tissue paper. This area of the abdomen was then subjected to gentle pressure, followed by sperm collection with a sterile syringe, which was then merged and mixed in a beaker. The beaker was placed in styrofoam with crushed ice $\left(4^{\circ} \mathrm{C}\right)$. Thus, the fresh sperm were characterized based on $\mathrm{pH}$, color, and consistency, and also for initial quality (motility and viability). Also, only sperm with minimum motility above $60 \%$ were used for cryopreservation (Muchlisin et al., 2020).

\section{Extender preparation}

The Ringer's solution used as an extender was prepared based on Muchlisin et al. (2004) as follows, $100 \mathrm{ml}$ comprised

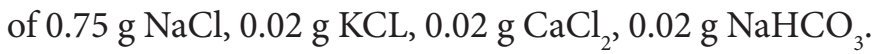
These materials were diluted in the distilled water to obtain $100 \mathrm{ml}$ volume, which was then placed at $4^{\circ} \mathrm{C}$ in the crushed ice, before use in the experiment.

\section{Cryoprotectant preparation}

The ICPAs (DMSO, methanol, ethanol, glycerol, and ethylene glycol) were purchased from the supplier (Sigma-Aldrich), and tested at 10\% concentration for each, while the egg yolk was extracted from chicken eggs purchased from a local market. A total of 100 Ringer's solutions were mixed with $5 \mathrm{ml}$ sperm, resulting in $105 \mathrm{ml}$ of sperm diluted at a ratio of $1: 20(\mathrm{v} / \mathrm{v}$, sperm: extender), followed by the addition of $10 \mathrm{ml}$ egg yolk. This solution was distributed into 18 cryotubes (vol. $2 \mathrm{ml}$ ) with each filled with $1.5 \mathrm{ml}$ solution (Ringer's + sperm + egg yolk). Then, $0.15 \mathrm{ml}$ of the respective cryoprotectant was added to obtain a final concentration of $10 \%$ ICPAs and 15\% egg yolk. Also, the control treatment was devoid of any ICPA, and all procedures were conducted at $4{ }^{\circ} \mathrm{C}$.

\section{Equilibration and thawing}

The equilibration process was initiated at $4^{\circ} \mathrm{C}$ in the crushed ice for $5 \mathrm{~min}$, followed by the removal of tubes, which were placed $5 \mathrm{~cm}$ above liquid nitrogen $\left(-79^{\circ} \mathrm{C}\right)$ for $5 \mathrm{~min}$, and immersed subsequently, at $-196^{\circ} \mathrm{C}$ for 15 days. This procedure is based on Muchlisin et al. (2015b), and after 14 days, the tubes were removed from the tank and thawed in a water bath $\left(30^{\circ} \mathrm{C}\right)$ for $5 \mathrm{~min}$. These sperm samples were then analyzed for quality, motility, viability, fertilization, and DNA integrity.

\section{Motility analysis}

One drop of cryopreserved sperm was activated using one drop of tap water on an object glass. This sample was then observed under a stereomicroscope, which was connected to a CCD camera, and monitored for live activity on the computer (400X magnification), as the motion was recorded as a videotape. Therefore, motility was calculated based on 50 randomly chosen spermatozoa previously recorded, which was then compared with the examination for fresh sperm (Muchlisin et al., 2020).

\section{Viability analysis}

One drop of cryopreserved sperm was mixed with one drop of $0.2 \%$ eosin dye on the glass object as a smear sample. This was then observed under a stereomicroscope at 400 magnification. Life was indicated by the presence of clarity and transparency, while rose-colored substance denoted death (Ax et al., 2000; Maulana et al., 2014). Therefore, the viability is calculated based on 200 randomly chosen spermatozoa, which was then compared with the examination for fresh sperm. 


\section{Eggs collection and fertility analysis}

The eggs were collected from two late mature female fish by applying gentle pressure from the abdomen to the genital pore. The eggs were batched into a plastic basin and kept in crushed ice $\left(4^{\circ} \mathrm{C}\right)$. A total of $0.25 \mathrm{ml}$ thawed diluted sperm (approximately $0.68 \times 109$ sperm cells ml-1) was mixed with $1 \mathrm{ml}$ of eggs (approximately 1,483 eggs), and then two drops of tap water were added and mixed homogeneously. This combination was allowed contact for $5 \mathrm{~min}$, to ensure egg fertilization. Therefore, a total of 100 eggs were taken at random and incubated in the plastic jars at a water temperature of $27^{\circ} \mathrm{C}$. A successful outcome is discernible at $2 \mathrm{~h}$ post-fertilization, based on the clear and transparent presentation of eggs, while opacity was used as an indicator for failure (Muchlisin et al., 2015b; Muthmainnah et al., 2018). The fertility rate was calculated as follows: Fertilization rate (\%) = total of fertilized eggs/total of incubated eggs $\mathrm{x} 100$.

\section{DNA extraction}

The DNA was extracted using the Genomic DNA Purification Kit (Promega, Malaysia), following the manufacturer's protocol. Approximately $100 \mu \mathrm{l}$ of pellet sperm tissue was transferred into a sterile $1.5 \mathrm{ml}$ tube, followed by the addition of $300 \mu \mathrm{l}$ cell lysis solution, and then the sperm was vortexed for $30 \mathrm{sec}$. This mixture was subsequently incubated at room temperature for $10 \mathrm{~min}$ and centrifuged at $15,000 \mathrm{rpm}$ for $20 \mathrm{sec}$. The supernatant was discarded and $100 \mu \mathrm{l}$ of nuclei lysis solution was added into the pellet before a re-vortex, which resulted in the lysate. A total of $35 \mu$ l protein precipitation solution (RNase Solution) was then added before another round of re-vortex for $20 \mathrm{sec}$, followed by centrifugation at 15,000 rpm for $3 \mathrm{~min}$. The supernatant was removed and placed into a new tube, and then $100 \mu$ of isopropanol was added and centrifuged at $15,000 \mathrm{rpm}$ for $1 \mathrm{~min}$. The resulting supernatant was discarded and an equal volume of $70 \%$ ethanol was added into the pellet before subjecting to another recentrifugation for $1 \mathrm{~min}$. The liquid was discarded and the pellet dried at room temperature for $15 \mathrm{~min}$. This was followed by hydration with $35 \mu \mathrm{DNA}$ rehydration solution, which was then incubated at $65^{\circ} \mathrm{C}$ for $1 \mathrm{~h}$, and the resulting medium was reserved at $2^{\circ} \mathrm{C}$ before use in electrophoresis.

\section{Electrophoresis}

A total of $2 \mathrm{~g}$ agarose was mixed with $100 \mathrm{ml}$ of $1 \mathrm{X}$ TBE buffer, which was then heated with a microwave at $250^{\circ} \mathrm{C}$ for $2 \mathrm{~min}$. Subsequently, $2 \mu \mathrm{l}$ of DNA dye was added and cast for $30 \mathrm{~min}$, followed by the removal of agar gel into the electrophoresis batch with a TBE buffer solution. A total of $10 \mu \mathrm{DNA}$ samples with $2 \mu \mathrm{l}$ loading dye were inserted into the wells, while about $5 \mu$ l DNA marker was introduced into different wells. The process of electrophoresis was conducted on a $0.8 \%$ agarose gel at 135 Volts for $30 \mathrm{~min}$, and on termination, the agar gel was placed onto the E-BOX VX2 gel documentation system to record the band image.

\section{Data analysis}

Data on sperm motility, viability, and fertility were subjected to a one-way ANOVA test, which was followed by Duncan's multiple range test at $95 \%$ confidence level, using the SPSS Ver. 20.0. Information obtained concerning $\mathrm{pH}$, color, sperm consistency, and DNA integrity was descriptively analyzed.

\section{Results}

The fresh sperm possessed milky-white coloration, with $\mathrm{pH} 6.4$, and sperm density of $3.1 \times 10^{9}$ cells $\mathrm{ml}^{-1}$. Also, $74.67 \%$ sperm motility, $77.03 \%$ viability, and $72.67 \%$ fertility were recorded, and assumed to be significantly affected by the introduction of cryoprotectants, based on the ANOVA test $(\mathrm{P}<0.05)$. After 15 days of cryopreservation, the highest values of sperm motility, sperm viability, and fertility were recorded in samples with DMSO, at $47.17 \%, 50.13 \%$, and $45.67 \%$, respectively (Table 1), which were significantly different from methanol, ethanol, glycerol and ethylene glycol. However, lower values were recorded in the various cryoprotectants after treatment. Moreover, the analysis of

Table 1 - Sperm motility, viability, and fertility of naleh fish Barbonymus sp. after 15 days of cryopreservation using several types of cryoprotectants i.e. DMSO, methanol, ethanol, glycerol, and ethyl glycol. The experiment was performed with three replications. The mean values $( \pm S D)$ with different superscript $(\mathrm{a}-\mathrm{f})$ in the same column are significantly different $(p<0.05)$.

\begin{tabular}{cccc}
\hline Treatment & Motility (\%) & Viability (\%) & Fertility (\%) \\
\hline 15\% egg yolk (control) & $38.17 \pm 0.28^{\mathrm{c}}$ & $42.00 \pm 0.26^{\mathrm{c}}$ & $36.33 \pm 0.57^{\mathrm{c}}$ \\
$10 \%$ DMSO + 15\% egg yolk & $47.17 \pm 0.28^{\mathrm{a}}$ & $50.13 \pm 0.45^{\mathrm{a}}$ & $45.67 \pm 0.57^{\mathrm{a}}$ \\
$10 \%$ Methanol + 15\% egg yolk & $44.83 \pm 0.28^{\mathrm{b}}$ & $49.10 \pm 0.34^{\mathrm{b}}$ & $42.67 \pm 0.57^{\mathrm{b}}$ \\
$10 \%$ Ethanol + 15\% egg yolk & $36.83 \pm 0.28^{\mathrm{d}}$ & $39.03 \pm 0.58^{\mathrm{e}}$ & $35.00 \pm 1.00^{\mathrm{d}}$ \\
$10 \%$ Glycerol + 15\% egg yolk & $30.17 \pm 0.28^{\mathrm{f}}$ & $33.83 \pm 0.47^{\mathrm{f}}$ & $25.67 \pm 0.57^{\mathrm{e}}$ \\
$10 \%$ Ethyl Glycol + 15\% egg yolk & $35.83 \pm 0.28^{\mathrm{e}}$ & $40.37 \pm 0.23^{\mathrm{d}}$ & $34.00 \pm 1.00^{\mathrm{d}}$ \\
\hline
\end{tabular}


DNA integrity showed the detection of no smear bands in all treatments, including the fresh samples, which indicates that the DNA fragmentation was not present in fresh and cryopreserved sperms (Figure 2).

\section{Discussion}

The fresh sperm of naleh was of good quality, based on the milky-white coloration, $\mathrm{pH}$ of $6.4,74.61 \%$ motility, the viability of $77.03 \%$, and fertility of $72.67 \%$. This outcome was congruent with Melo \& Godinho (2006), which reported on the characteristic milky-white color, slightly acidic $\mathrm{pH}$ of between pH 5.0-7.0 (Setyono, 2009), and the initial motility of above $70 \%$ (Christensen \& Tiersch, 2005). The study revealed a reduction in sperm quality after treatment, although significantly higher values were reported with the DMSO cryoprotectant. Hence, this is the basis for its selection as the best for naleh fish sperm.

DMSO was also suitable for the sperm of depik fish Rasbora tawarensis (Muchlisin et al., 2020), seurukan fish Osteochillus vittatus (Muthmainnah et al., 2018), African catfish Clarias gariepinus (Omitogun et al., 2010), Mugil cephalus (Balamurugan et al., 2019), Barbus grypus (Dogu, 2012), common carp Cyprinus carpio (Irawan et al., 2010), and mahseers Tor tambroides and T. dauronensis (Chew et al., 2010). However, the concentration of DMSO used is species-dependent. For example, the best dilution for $R$. tawarensis was 5\% (Muchlisin et al., 2020), 10\% for C. carpio (Irawan et al., 2010), and 10\% for B. grypus sperm (Dogu, 2012). This study showed the use of a single

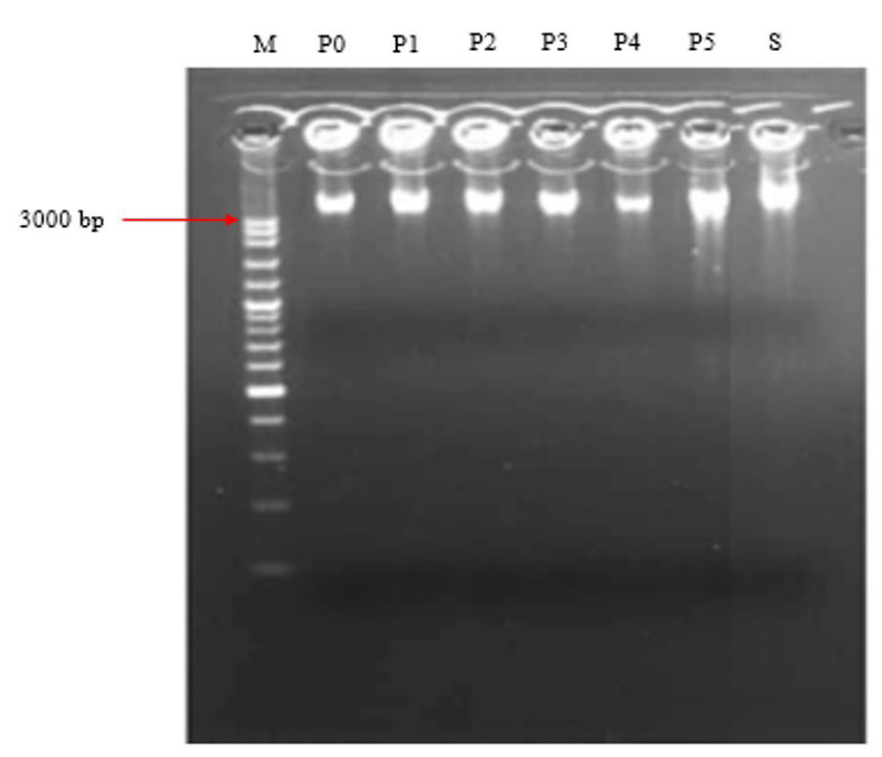

Figure 2 - The electrophoresis analysis of fresh and cryopreserved sperm of naleh fish Barbonymus sp. $\mathrm{M}=$ marker; $\mathrm{P} 0=15$ egg yolk (control); $\mathrm{P} 1=\mathrm{DMSO}$; $2=$ =methanol; $\mathrm{P} 3=$ ethanol; P4=glycerol; P5=ethyl glycol, $\mathrm{S}=$ fresh sperm. concentration across all CPAs. Further investigations need to determine the best concentration of DMSO specific to naleh fish spermatozoa.

Leibo \& Pool (2011) observed that DMSO is a neutral solution, which acts as an intracellular CPA. This is known to protect against temperature shocks within the sperm cell during the freezing and thawing process. Meanwhile, the egg yolk confers external shields during cryopreservation, particularly from the loss or entry of fluids, which often results from differences in osmotic pressure on storage (Bozkurt et al., 2014; Laeni et al., 2020; Muchlisin, 2005). This phenomenon occurs because of the low-density lipoprotein content, which associates easily with the cell membrane, subsequently providing a protective mechanism (Babiak et al., 2002). Therefore, the egg yolk is commonly combined with other intracellular cryoprotectants.

Temperature shock triggers damage to cell membranes and intracellular organelles, as well as changes in permeability and the lipid components of the membrane. This causes a reduction in flagella activity, leading to a decline in sperm motility and viability (Ogbuewu et al., 2010). Gazali \& Tambing (2002) reported on the tendency for the freezing process to form ice crystals with the capacity to physically injure sperm cells. Furthermore, there is also an increase in the amount of intracellular enzyme released, leading to the damage of lysosomes and mitochondria.

An interesting finding was recorded in sperm cryopreserved with egg yolk without ICPA, which showed higher motility, viability, and fertility, compared to the combination with ethanol, glycerol, and ethylene glycol. This outcome probably results from the toxic effect of these ICPAs at the concentration of use, which is higher than DMSO and methanol. Therefore, the sperm quality after cryopreservation was reduced, making them unsuitable, according to Muchlisin \& Azizah (2009), due to the detrimental effect on the sperm cells of the tropical river catfish, Mystus nemurus.

Cryoprotectants play a crucial role in this preservation process, although toxicity has been recorded at higher concentrations, which possibly leads to sperm death. For example, the use of $15 \%$ methanol, N, N-dimethyl acetamide (DMA), and DMSO produced higher toxicity on Zebrafish Danio rerio than the $10 \%$ and $5 \%$ treatments. However, each cryoprotectant has a unique lethal level at the same concentration, e.g., glycerol was more toxic than DMA and DMSO on zebrafish sperm (Yang et al., 2007; Yang \& Tiersch, 2009). Saragusty \& Arav (2011) found that these effects were capable of disrupting the permeability of the 
cell membrane, alongside changes in osmotic pressure, and ultimately damage sperm DNA.

The analysis of DNA fragmentation showed the absence of any smear band in the treatments and fresh sperm samples. This indicates similarity in DNA quality, as the DNA was unchanged during the cryopreservation process. This finding confirms the ability of all cryoprotectants tested to confer protective effects on DNA integrity. Bhattacharya (2018) proposed the capacity to ensure slow freezing as the damage preventive measure. Also, DNA fractionation during the process of cryopreservation possibly occurs because of increased calcium concentrations within the cells, which stimulate endonuclease activity. This leads to the formation of reactive oxygen species (ROS), subsequently elevating the incidence of peroxidation, and the formation of genotoxic components, which cause damage to inherent bonds (Cabrita et al., 2005; Leibo \& Pool, 2011).

Besides, damage to the DNA does not always affect motility and fertility, as seen in brown-marbled grouper, Epinephelus fuscoguttatus (Yusoff et al., 2018). Upadhya et al. (2010) found that the affected sperm with good motility possess the capacity to fertilize an egg, followed by the development of potentially damaged genomes, and, consequently, causing larvae abnormality. Horvath \& Urbanyi (2001) recorded higher amounts of abnormal larvae in eggs fertilized using cryopreserved sperm, of which some were

\section{References}

Abinawanto A, Rahayu S, Lestari R. Cryopreservation of java barb (Barbonymus gonionotus) using egg yolk as a cryoprotectant. Glob Vet. 2013;10(3):318-21.

Abinawanto A, Wulandari R, Muchlisin ZA. Effect of egg yolk on the spermatozoa quality of the botia Chrombotia macracanthus (Bleeker, 1850) (Cyprinidae) after short-term cryopreservation. Aquacult Aquarium Conserv Legis. 2018;11(6):1737-44.

Afriani D, Eriani K, Muchlisin ZA, Hasri I. A short review of discovery and development of fish sperm cryopreservation. Depik J Ilmu Perair Pesis Perik. 2021;10(1):10-5.

Agarwal NK. Cryopreservation of semen fish. In: Thapliyal M, Thapliyal A, Bhatt JP, editors. Himalayan aquatic biodiversity conservation and new tools in biotechnology. England: Transmedia Publication; 2011. p. 104-27. haploid (Miskolczi et al., 2005). This particular outcome was, however, not observed in the current study.

\section{Conclusion}

We found that cryoprotectants significantly affect the motility, viability, and fertility of cryopreserved sperm, and no DNA fragmentation was detected in fresh and cryopreserved sperm. Also, a combination of $10 \%$ DMSO with $15 \%$ egg yolk was the best cryoprotectant for naleh fish sperm.

\section{Conflict of Interest}

No conflict of interest was declared.

\section{Ethics Statement}

The study complies with the guidelines of ethical animal use in research of Syiah Kuala University (Kode Etik Penelitian Universitas Syiah Kuala Tahun 2015).

\section{Acknowledgements}

This study was supported by the Syiah Kuala University through the Professorship scheme 2019. Therefore, the author thanks the Rector of Syiah Kuala University for supporting this study. The assistance of all members of Ichthyos Research Group and Mr. Khaidir from Blang Adei Jaya Hatchery is also acknowledged.

Ax RL, Dally M, Didion BA, Lenz RW, Love CC, Varner DD, Hafez B, Bellin ME. Semen evaluation. In: Hafez B, Hafez ESE, editors. Reproduction in farm animals. 6th ed. Filadélfia: Lippincott Williams \& Wilkins; 2000. p. 363-75. http://dx.doi.org/10.1002/9781119265306.ch25.

Babiak I, Glogowski J, Dobosz S, Kuzminki H, Goryczko K. Semen from rainbow trout produced using cryopreserved sperma is more suitable for cryopreservation. J Fish Biol. 2002;60(3):561-70. http://dx.doi.org/10.1111/j.1095-8649.2002. tb01684.x.

Balamurugan R, Prapaporn W, Munuswamy N. Sperm activation and effects of cryopreservation on motility, ultrastructure and DNA integrity in grey mullet Mugil cephalus. Aquacult Rep. 2019;14:1-9. http://dx.doi.org/10.1016/j. aqrep.2019.100204.

Batubara AS, Muchlisin ZA, Efizon D, Elvyra R, Fadli N, Rizal S, Siti-Azizah MN, Wilkes M. DNA barcoding (COI genetic marker) revealed hidden diversity of Cyprinid fish 
(Barbonymus spp.) from Aceh Waters, Indonesia. Biharean Biol. 2021;15(1):e201306.

Batubara AS, Muchlisin ZA, Efizon D, Elvyra R, Fadli N, Irham M. Length-weight relationships and condition factors of the naleh fish, Barbonymus gonionotus (Pisces, Cyprinidae) harvested from Nagan Raya waters, Indonesia. Vestn Zool. 2019a;53(1):75-82. http://dx.doi.org/10.2478/vzoo-2019-0008.

Batubara AS, Efizon D, Elvyra R, Rizal S, Muchlisin ZA. Population dynamics of the naleh fish Barbonymus sp. (Pisces: Cyprinidae) in Nagan River waters, Aceh Province, Indonesia. Jordan J Biol Sci. 2019b;12(3):361-6.

Batubara AS. Bioekologi dan genetika ikan Naleh (Barbonymus sp.) sebagai dasar pengembangan budidaya [Ph.D thesis]. Banda Aceh: Universitas Syiah Kuala; 2019.

Batubara AS, Muchlisin ZA, Efizon D, Elvyra R, Fadli N, Irham M. Morphometric variations of the Genus Barbonymus (Pisces, Cyprinidae) harvested from Aceh Waters, Indonesia. Fish and Aquat Life. 2018;26:231-7.

Bhattacharya S. Cryopretectants and their usage in cryopreservation process. Biomed Biol Sci. 2018;80477:719. http://dx.doi.org/10.5772/intechopen.80477.

Blaxter JHS. Sperm storage and cross-fertilization of spring and autumn spawning herring. Nature. 1953;172:1189-90.

Bozkurt Y, Yavas I, Yildiz C. Effect of different avian egg yolk types on fertilization ability of cryopreserved common carp (Cyprinus carpio) spermatozoa. Aquacult Int. 2014;22(1):131-9. http://dx.doi.org/10.1007/s10499013-9728-4.

Cabrita E, Robles V, Rebordinos L, Sarasquete C, Herráez MP. Evaluation of DNA damage in rainbow trout (Oncorhynchus mykiss) and gilthead sea bream (Sparus aurata) cryopreserved sperm. Cryobiology. 2005;50(2):144-53. http://dx.doi. org/10.1016/j.cryobiol.2004.12.003. PMid:15843004.

Chao NH, Liao IC. Cryopreservation of finfish and shellfish gametes and embryos. Aquacult. 2001;197(1-4):161-89. http://dx.doi.org/10.1016/S0044-8486(01)00586-5.

Chew PC, Abd-Rashid Z, Hassan R, Asmuni M, Chuah HP. Semen cryobank of the malaysian mahseer (Tor tambroides and T. douronensis). J Appl Ichthyology. 2010;26(5):726-31. http://dx.doi.org/10.1111/j.1439-0426.2010.01552.x.

Christensen JM, Tiersch TR. Cryopreservation of channel catfish sperm: effects of cryoprotectant exposure time, cooling rate, thawing conditions and male to male variation. Theriogenology. 2005;63(8):2103-12. http://dx.doi. org/10.1016/j.theriogenology.2004.08.013. PMid:15826676.

Dogu Z. Cryopreservation of semen in shabout (Barbus grypus Heckel, 1843) sperm motility and fertilization rates. J Appl Ichthyology. 2012;28(6):952-5. http://dx.doi. org/10.1111/jai.12072.

Gazali M, Tambing SN. Kriopreservasi sel spermatozoa. Hayati. 2002;9(1):27-32.

Hiemstra SJ, Van der Lende T, Woelders H. The potential of cryopreservation and reproductive technologies for animal genetic resources conservation strategies. In: Proceedings of the Symposium Role of Biotechnology; 2005 March 5-7; Villa Gualino, Turin. 2005. p. 25-35.

Horvath A, Urbanyi B. The effect of cryoprotectants on the motility and fertilizing capacity of cryopreserved african catfish Clarias gariepenus (Burchell, 1822) sperm. Aquacult Res. 2001;31(3):317-24. http://dx.doi.org/10.1046/j.13652109.2000.00444.x.

Irawan H, Vuthiphandchai V, Nimrat S. The effect of extenders, cryoprotectants and cryopreservation methods on common carp (Cyprinus carpio) sperm. Anim Reprod Sci. 2010;122(3-4):236-43. http://dx.doi.org/10.1016/j. anireprosci.2010.08.017. PMid:20863635.

Laeni M, Abinawanto A, Subagja J, Kristanto AH. The effect of various concentration of quail egg yolk on spermatozoa motility of kancra fish (Tor soro Valenciennes, 1842) post cryopreservation. IOP Publishing. 2020;441:1-6. http:// dx.doi.org/10.1088/1755-1315/441/1/012060.

Leibo SP, Pool TB. The principal variables of cryopreservation: solutions, temperatures, and rate changes. Fertil Steril. 2011;96(2):269-76. http://dx.doi.org/10.1016/j. fertnstert.2011.06.065. PMid:21782053.

Maulana F, Alimuddin A, Junior MZ. Morfologi, fisiologi, preservasi sel sperma ikan betok (Anabas testudineus, Bloch 1792) dan ketahanannya terhadap kejut listrik. J. Ikhtiologi Indonesia. 2014;14:211-23.

Melo FCSA, Godinho HP. A protocol for cryopreservation of sperm of the fish Brycon Orthotaenia. Anim Reprod. 2006;3:380-5.

Miskolczi E, Mihalffy S, Varkonyi EP, Urbanyi B, Horvath A. Examination of larval malformations in african catfish (Clarias gariepinus) following fertilization with cryopreserved sperm. Aquaculture. 2005;247(1-4):119-25. http://dx.doi. org/10.1016/j.aquaculture.2005.02.043. 
Muchlisin ZA, Hashim R, Chong AS. Preliminary study on the cryopreservation of tropical bagrid catfish (Mystus nemurus) spermatozoa; the effect of extender and cryoprotectant on the motility after short-term storage. Theriogenology. 2004;62(1-2):25-34. http://dx.doi. org/10.1016/j.theriogenology.2003.05.006. PMid:15159098.

Muchlisin ZA, Azizah MNS. Influence of cryoprotectants on abnormality and motility of baung (Mystus nemurus) spermatozoa after long-term cryopreservation. Cryobiology. 2009;58(2):166-9. http://dx.doi.org/10.1016/j.cryobiol.2008.11.010. PMid:19114036.

Muchlisin ZA, Akyun Q, Rizka S, Fadli N, Sugianto S, Halim A, Siti-Azizah MN. Ichthyofauna of Tripa peat swamp forest, Aceh province, Indonesia. Check List. 2015a;11(2):1560-9. http://dx.doi.org/10.15560/11.2.1560.

Muchlisin ZA, Nadiah WN, Nadiya N, Fadli N, Hendri A, Khalil M, Siti-Azizah MN. Exploration of natural cryoprotectants for cryopreservation of african catfish, Clarias gariepinus, Burchell 1822 (Pisces: Clariidae) spermatozoa. Czech J Anim Sci. 2015b;60(1):10-5. http:// dx.doi.org/10.17221/7906-CJAS.

Muchlisin ZA, Sarah PI, Aldila DF, Eriani K, Hasri I, Batubara AS, Nur FM, Mustaqim M, Muthmainnah CR, Abinawanto A, Wilkes M. Effect of dimethyl sulfoxide (DMSO) and egg yolk on sperm motility, fertility and hatching rate of depik Rasbora tawarensis (Pisces: Cyprinidae) eggs after shortterm cryopreservation. Aquacult Res. 2020;51(4):1700-5. http://dx.doi.org/10.1111/are.14516.

Muchlisin ZA. Current status of extenders and cryoprotectants on fish spermatozoa cryopreservation. Biodiversitas (Surak). 2005;6(1):66-9.

Muchlisin ZA. Ikan air tawar di Nanggroe Aceh Darussalam dan kawasan ekosistem Leuser. Paneco: Universitas Syiah Kuala-Universiti Sains Malaysia; 2008

Muchlisin ZA. Potency of freshwater fishes in Aceh waters as a basis for aquaculture development program. J. Ikhtiologi Indonesia. 2013;13(1):91-6.

Muthmainnah CR, Eriani K, Hasri I, Irham M, Batubara AS, Muchlisin ZA. Effect of glutathione on sperm quality after short-term cryopreservation in seurukan fish Osteochilus vittatus (Cyprinidae). Theriogenology. 2018;122:30-4. http://dx.doi.org/10.1016/j.theriogenology.2018.08.024. PMid:30227301.

Ogbuewu IP, Aladi NO, Etuk IF, Opara MN, Uchegbu MC, Okoli IC, Iloeje MU. Relevance of oxygen free radicals and antioxidants in sperm production and function. Res J Vet Sci. 2010;3(3):138-64. http://dx.doi.org/10.3923/rjvs.2010.138.164.

Omitogun OG, Olaniyan OF, Oyeleye OO, Ojiokpota C, Aladele SE, Odofin WT. Potentials of short term and long term cryopreserved sperm of the african giant catfish (Clarias gariepinus Burchell, 1822) for aquaculture. Afr J Biotechnol. 2010;9:6973-82.

Saragusty J, Arav A. Current progress in oocyte and embryo cryopreservation by slow freezing and vitrification. Reproduction. 2011;141(1):1-9. http://dx.doi.org/10.1530/ REP-10-0236. PMid:20974741.

Sarder MRI, Sarker MFM, Saha SK. Cryopreservation of sperm of an indigenous endangered fish species Nandus nandus (Hamilton, 1822) for ex-situ conservation. Cryobiology. 2012;65(3):202-9. http://dx.doi.org/10.1016/j. cryobiol.2012.06.004. PMid:22750204.

Setyono B. Pengaruh perbedaan konsentrasi bahan pada pengencer sperma ikan "skim kuning telur" terhadap laju fertilisasi, laju penetasan dan sintasan ikan mas (Cyprinus carpio L.). Gamma. 2009;5(1):1-12.

Upadhya D, Kalthur G, Kumar P, Rao BS, Adiga SK. Association between the extent of DNA damage in the spermatozoa, fertilization and developmental competence in preimplantation stage embryos. J Turk Ger Gynecol Assoc. 2010;11(4):182-6. http://dx.doi.org/10.5152/jtgga.2010.34. PMid:24591933.

Yang H, Carmichael C, Varga ZM, Tiersch TR. Development of a simplified and standardized protocol with potential four high-throughput for sperm cryopreservation in zebrafish Danio rerio. Theriogenol. 2007;68(2):1192-9. http://dx.doi. org/10.1016/j.theriogenology.2007.02.015.

Yang H, Tiersch TR. Current status of sperm cryopreservation in biomedical research fish models: Zebrafish, Medaka and Xiphophorus. Comp Biochem Physiol C Toxicol Pharmacol. 2009;149(2):224-32. http://dx.doi.org/10.1016/j. cbpc.2008.07.005. PMid:18691673.

Yusoff M, Hassan BN, Ikhwanuddin M, Sheriff SM, Hashim F, Mustafa S, Koh IVC. Successful sperm cryopreservation of the brown-marbled grouper, Epinephelus fuscoguttatus using propylene glycol as cryoprotectant. Cryobiology. 2018;81:168-73. http://dx.doi.org/10.1016/j.cryobiol.2018.01.005. PMid:29355519.

Financial Support: This study was supported by Universitas Syiah Kuala through Professorship Research Grant 2019. 